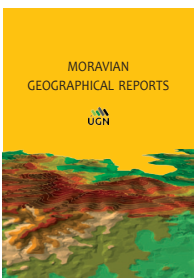

\title{
Viticultural landscapes: Localised transformations over the past 150 years through an analysis of three case studies in Slovakia
}

\author{
Dagmar ŠTEFUNKOVÁ a *, Ján HANUŠIN ${ }^{b}$
}

\begin{abstract}
The transformation of vineyard landscapes is evaluated in this article by assessing the changes in land cover and landscape diversity in selected study areas in two time periods - from 1867 to 1949, and from then to 2016. The study areas are characterised by a long history of viticulture and with important occurrences of old and new agrarian relief forms. Fine-scale land cover and landscape diversity analysis, as well as the study of historical and strategic documents, enabled an accurate interpretation of the viticultural landscape trajectories and their drivers. Landscape diversity was computed using the Shannon diversity index for each 625 square metre grid unit, and applying other metrics for the entire study area. Our research established that the study areas oscillated during this period between extensification and agricultural intensification, and the general trend confirmed the disappearance of traditional vineyards and a decline in modernised vineyard areas after socialism. Although extensification and intensification are seemingly contradictory processes, it is established that these both increase landscape diversity. In addition, landscape diversity changes in the second period are influenced more by changes in quantitative landscape pattern characteristics via edge density than qualitative patterns, e.g. patch richness, which reflect land use diversity.
\end{abstract}

Keywords: vineyard transformation, vineyard terraces, land cover, landscape diversity, change drivers, Slovakia

Article history: Received 28 January 2019, Accepted 10 September 2019, Published 30 September 2019

\section{Introduction}

The viticultural landscape is one of the oldest types of cultural and cultivated landscapes in Europe and it creates a unique genius loci in many regions with its distinctive function and appearance. It also forms a special part of the agricultural landscape and has therefore been intensively studied. Examples include the following different contexts: the physical-geographical background (Biddoccu et al., 2016; Comino et al., 2017; Lieskovský and Kenderessy, 2014); economic efficiency (Costantini et al., 2016; González et al., 2017; Torquati et al., 2015); ecosystem services (Garcia et al., 2018; Winkler and Kimberly, 2016) and land cover (LC) changes (Greinert et al., 2019; Vinatier and González-Arnaiz, 2018).

Terraced vineyards are among the oldest examples of cultural landscapes in Europe and studies focused on these present important research (Haffke, 1994; Ramos and Porta, 1997; Rodrigo-Comino et al., 2019; Tarolli et al., 2014), especially the dry-stone terrace vineyards spread mainly throughout Mediterranean areas (Barbera and Motisi, 2017). Terraced viticulture in Central Europe was previously assumed to begin between the $10^{\text {th }}$ and $14^{\text {th }}$ centuries, but indirect archaeological and archival findings indicate its earlier occurrence around the $4^{\text {th }}$ to $5^{\text {th }}$ centuries (Petit et al., 2012). In addition, an overview study of terraced landscapes was performed by Wei et al. (2016), following Stanchi et al.'s (2012) recording of considerable traditional terraced agricultural systems in marginal, steeply sloping areas in the Alpine, Mediterranean and Sub-Mediterranean regions.

The wave of building and modernisation of the European Union (EU) vine-growing terraces, especially those in the Mediterranean, occurred in the 1980-1990s (Borselli et al., 2006; Cots-Folch et al., 2006). After 2000 this process was connected to the EU implementation of the Common Agricultural Policy (CAP - Commission Regulation EC

\footnotetext{
${ }^{a}$ Institute of Landscape Ecology, Slovak Academy of Sciences, Bratislava, Slovak Republic (*corresponding author: D. Štefunková, e-mail:dagmar.stefunkova@savba.sk)

${ }^{\mathrm{b}}$ Institute of Geography, Slovak Academy of Sciences, Bratislava, Slovak Republic
} 
No. $1227 / 2000$ of 31 May 2000; Martínez-Casasnovas et al., 2010). The CAP subsidies strongly encouraged the establishment of large-scale vine-growing terraces. The establishment of large-scale vine-growing terraces, however, caused many environmental problems such as erosion, soil degradation, landslides and the disappearance of the traditional wine-growing landscape (Cots-Folch et al., 2006, 2009; Ramos et al., 2007).

Despite the lack of sufficient archaeological and archival data on Slovak traditional terraced vineyards, there is indirect evidence that the oldest systems of vineyard terraces in the Little Carpathians region may have had their origin in the Middle Ages, because this was already a prosperous vineyard region in the $14^{\text {th }}$ century (Drábiková, 1989; Lukniš, 1977; Slavkovský, 2009; Špulerová et al., 2017). Mechanisation was not feasible, however, because of the divided plot structure, the amount of dry-stone terraces and the huge stone walls along the plot boundaries. Vine-growing modernisation in Slovakia, which aimed to counteract the shortcomings of traditional wine-making, began during the state-controlled intensification of agriculture under socialism. Vineyard transformation with construction of terraces compatible with mechanisation also occurred in the second half of the $20^{\text {th }}$ century in other socialist countries, such as Hungary and Slovenia (Borselli et al., 2006; Momirski and Kladnik, 2009; Pipan and Kokajl, 2017).

Given this background, the main aim of this study is to evaluate vineyard landscape transformations by identifying and assessing the land cover (LC), landscape diversity (LDI) and related factors in the time period spanning the change from free market to socialist economies. This evaluation emphasises the transformation of the traditional landscape into the modern collectivised structure.

The first period of change covers the relative continuity in property relationships under market economy conditions, and the second period captures collectivisation under a directed centrally-managed socialist economy and subsequent changes due to its collapse.The modern winegrowing landscape is composed of large-block vineyards and vineyards on bench terraces. All the impacts on vineyard diversity from landscape collectivism, terrace construction and vineyard abandonment, however, have not yet been sufficiently developed.

In this research project, we assumed that:

- Assessment of the trajectories of changes in land cover and landscape diversity, which are characterised by a significant proportion of agrarian relief forms at a detailed scale, enables the identification of those landscape processes and features that cannot be realised by standard LC and LDI research methods and measures;

- Trends in parallel extensification and intensification, especially typical of European agricultural land in the $20^{\text {th }}$ century, are evident in the study areas (van Vliet et al., 2015). In countries under socialist collectivism, these are conditioned by both global and specialised drivers;

- Extensification and abandonment exhibit similar intensity in both traditional landscapes and the largescale vineyards created under collectivisation; and

- Increased diversity of the vine-growing landscape determines both extensification in its usage and intensification associated with vineyard terrace construction.

\section{Data and methods}

In this paper we have analysed the land cover and landscape diversity for three study areas at three different points in time:

1. The state of the study areas in the second half of the $19^{\text {th }}$ century is identified in Seleštany (1867), Modra (1894) and Svätý Jur (1896). This depicts the effects of agricultural intensification, industrial development and overseas trade and transport. The Slovak territory at that time was part of the Austro-Hungarian Empire, and maps of stable cadastres in the original 1:2,880 scale were used in LC analysis;

2. The period after the Second World War and before socialist agricultural collectivism is reflected in the 1949 recorded landscape changes - in the late $19^{\text {th }}$ century and the first half of the $20^{\text {th }}$. This was greatly influenced by the 1930's economic crisis, two World Wars, the collapse of the Austro-Hungarian Empire and the constitution of an independent Czechoslovakia. In this case, black-and-white aerial photographs from 1949 of the Historická ortofotomapa (C) GEODIS SLOVAKIA, s.r.o. a Historické LMS @ C Topografický ústav in Banská Bystrica, and the 1:5,000 1955 state map provided the substantive basis for our analysis. Period photographs and postcards were used as supporting documentation for some study areas for this year; and

3. Landscape analysis in Modra in 2015 and in Svätý Jur and Seleštany in 2016, established the current situation. This demonstrates the 1950-1980 landscape changes during socialist collectivism, the post-socialist restitution, the 1990-2000 agriculture transformation and the 2004 Slovak accession to the EU. The 2003 aerial orthophotos (Ortofotomapa (C) EUROSENSE s.r.o. a GEODIS SLOVAKIA) and rectified orthophotos from Google Earth 2016 Digital Globe, were verified by field research, and these provided the bases for our current land cover evaluation.

Hence, we evaluated the LC and LDI changes in the period between the chosen $19^{\text {th }}$ century years and $1949\left(1^{\text {st }}\right.$ period $)$ and between 1949 and 2015/2016 ( $2^{\text {nd }}$ period). The years for large-scale LC and LDI analysis were chosen in particular because of the availability of detailed and relatively reliable data. Additional monographs on the municipalities also offered relevant data on LC changes. (Antolov, 2007; Hodási, 2007; Turcsány, 2009; Žudel et al., 2006).

Details for the LC element classification were limited by source materials. In the second half of the $19^{\text {th }}$ century this was due to the lack of aerial images, and the 1949 black-andwhite aerial photographs have noticeably inferior quality compared to the current coloured orthophotos. We chose a minimal $15 \mathrm{~m}^{2}$ mapping unit and $2 \mathrm{~m}$ minimal line-shape width to maintain consistent mapping detail for all three years, and the proposed LC classification was best adapted to conform to the $19^{\text {th }}$ century stable cadastre maps, which had the least information content.

The complementary growth of fruit and vegetable crops was common in traditionally cultivated vineyards at that time (Agnoletti, 2015; Foški and Zavodnik, 2019), and the LC interpretation was therefore based on the $4^{\text {th }}-6^{\text {th }}$ hierarchy Corine Land Cover (CLC) levels sufficiently adapted to local characteristics and the diverse vineyard landscapes (see Appendix 1). We then implemented a detailed vineyard landscape classification system which could track landscape changes in the study periods. The identified vineyards 
were subdivided into class 221 CLC vineyards and class 24 heterogeneous agricultural areas, where they are combined with crops in agricultural mosaics.

Class 221 was delimited in two distinct lower levels: largeblock vineyards: internally homogeneous and over $5,000 \mathrm{~m}^{2}$, and small-block narrow-stripped vineyards. The division of modern terraced vineyards into vineyards on bench terraces and into slopes of bench terraces is important in this context, because it makes the LC categories more precise in tracking land use changes and affecting the resultant LDI values and their changes over time. We then identified the typical agrarian stone walls and mounds of the traditional vineyard landscape as a distinct class.

The landscape changes were assessed by analysing LC element area changes over the studied periods. In this case, overlain GIS maps provided source material for LC assessment in the individual study areas and individual years, and the areal extent of changes in particular LC classes were compared in contingency tables. The LC changes were then classified according to the following modifications adapted from Feranec et al. (2010): 1) afforestation (A); 2) succession (S); 3) agricultural extensification (E); 4) deurbanisation (D); 5) open woodland (WO); 6) deforestation (DE); 7) agricultural intensification (I); 8) urbanisation (U); 9 ) without change $(\mathrm{W})$; and 10 ) other changes $(\mathrm{O})$.

To understand the changes in the landscape, we analysed the driving forces that were influential processes in the evolutionary trajectory of the landscape and can be defined at spatial, temporal and institutional scales (Bürgi et al., 2004). We then identified natural, political, technological and economic drivers in the case study areas (Bürgi et al., 2004; Kanianska et al., 2014; Skokanová et al., 2016).

Our detailed scale of analysis, which was enabled by the use of grid units with an area of $25 \times 25 \mathrm{~m}\left(625 \mathrm{~m}^{2}\right)$ is different to some other studies utilising square grids. We chose the size of the grid basic unit so that the smallest analysed LC polygon of the $4^{\text {th }}-6^{\text {th }}$ CLC hierarchical level would be smaller than the square size.

The Shannon diversity index (SHDI) from the Fragstat programme manual (McGarigal et al., 2012) was chosen for the assessment of the LDI state and changes. The acquired SHDI values were plotted as map colour-coding for the various LDI degrees, ranging from 0 for lack of diversity to a maximum of 5 . Partial sets of SHDI $>0$ values for individual study areas and individual periods were merged into one file. Five value intervals were assigned by the equal interval method from the value range of the merged file as LDI degree classes, and this covered all three study periods and all years. This enabled the comparison of the LDI values between individual study areas and periods.

We then evaluated the LDI value and intensity changes as SHDI value differences in individual years. The resultant SHDI value-difference files were divided by the 6 equal interval method, and squares with zero change were set separately. As previously, we considered the entire LDI changed value range from all study areas and both periods to construct the intervals. This enabled comparison between the individual study areas and periods. In addition to the SHDI calculation for the individual grid squares, metrics unable to be effectively analysed in the grid were calculated for the entire study area and then analysed. The selection and calculation of these metrics was based on the Fragstat manual (McGarigal et al., 2012):

\section{SHDI index;}

2. number of patch types per ha (PRha);

3. number of patches/ha (NPha); and

4. total edge length in $\mathrm{m} / \mathrm{ha}$ (TEha).

The correlation coefficient $(r)$ matrix enabled the detection of the relationships between selected metrics and especially between these and grid-based LDI values and the grid-averaged and overall SHDI values. The r-value signified strong correlation and this was established for our low number of data-sets at 0.91 with $99 \%$ confidence ( $\mathrm{n}=9: 3$ study areas $\times 3$ periods) (Pavlík and Kühnl, 1981). The intensity of change over a period was assessed by correlating SHDI values over the grid between the two years, bracketing the period. Higher r-values denote greater similarity in LDI value distribution and smaller LDI changes over the relevant period.

\section{Study areas}

The three case study areas are depicted in Figure 1. The 66.2 ha Svätý Jur and 87.8 ha Modra study areas have similar natural backgrounds and are situated northeast of Bratislava on the south-eastern slopes of the Little Carpathian mountains. The geological composition is dominated by granites, and altitudes vary from 144 to $333 \mathrm{~m}$ a.s.l. in Svätý Jur and 174 to $349 \mathrm{~m}$ in Modra. The Svätý Jur study area relief is slightly more dissected than Modra. There is no well-developed permanent river system and loamy-sand cambisoils are the prevalent soil cover, but this is converted to culti-soils by regular vineyard cultivation and terracing. The climate is moderately warm and dry, with mean annual temperatures above $9{ }^{\circ} \mathrm{C}$ and average annual precipitation between 550 and $600 \mathrm{~mm}$. Only island residues of the original oak-hornbeam Carpathian forests, oak and Turkey-oak forest communities are still preserved.

These two areas are among the oldest vine-growing regions in Slovakia. The first mention of vineyards in the Little Carpathians dates back to the $13^{\text {th }}$ and $14^{\text {th }}$ centuries, and vine production underwent its greatest boom in the $16^{\text {th }}$ and $17^{\text {th }}$ centuries and it remained the most significant economic activity in this region by the end of $19^{\text {th }}$ and beginning of the $20^{\text {th }}$ centuries. The many old stone walls and mounds are now part of the cultural landscape heritage, and these agrarian landforms, sometimes up to $200 \mathrm{~m}$ long and $3 \mathrm{~m}$ high, originated over the centuries by removal of stones for land cultivation. They consist predominantly of granite debris, but they do not occur in Seleštany because of its different geological base.

In contrast, the 56.7 ha Seleštany study area is located in the Juhoslovenská Kotlina basin in south-central Slovakia on the Hungarian border, and the first records of vine-growing there come from the $14^{\text {th }}$ and $16^{\text {th }}$ centuries (Hodási, 2007). The altitudes of the currently terraced territory vary from 147 to $249 \mathrm{~m}$ a.s.l and there is no permanent river system. While the higher, less dissected parts of the study area are covered by eolic deluvial sediments, more resistant oligocene calcareous clastic sediments prevail on the steeper slopes along the northern and southern peripheries. The original soil cover has been transformed from pararendzinas and brown soils to culti-soils, and there are no remnants of the original vegetation cover or oak-hornbeam and Turkey oak forests. The study area is situated in a warm, dry region with a moderate winter and average annual precipitation between 550 and $570 \mathrm{~mm}$. 


\section{Results}

\subsection{Land cover changes}

We analysed the land cover in the study areas and the changes over time using CLC $3^{\text {rd }}$ level classes (Fig. 2). This provided a reliable basic overview of the transformations.

Vineyards were a dominant element in all three study areas in the $19^{\text {th }}$ century (Fig. 2). Although the largest proportion of vineyards was in Seleštany, over 50\% of the Svätý Jur area also had cultivated vineyards. The $4^{\text {th }}-6^{\text {th }}$ CLC hierarchical levels reveal that small-block staked vineyards predominated in Svatý Jur and Seleštany, while Modra had small block staked vineyards on stone-walled terraces.

By 1949, however, the proportion of vineyards in Seleštany plunged from $82 \%$ to $8 \%$, and $38 \%$ of the total area had complex cultivation patterns as the dominant land cover type. The decrease in the vineyard area in Svätý Jur was more moderate at that time, and grapevines remained the prevailing land cover type. In direct contrast, the Modra vineyard area increased from $33 \%$ to $49 \%$ in the studied area. In addition, the the remarkable $19^{\text {th }}$ century historical area of agrarian stone walls and mounds which covered $6-8 \%$ of Modra and Svätý Jur had not significantly changed by 1949.

One notes that by 2015 in Modra and 2016 in Seleštany and Svätý Jur, there were marked study area changes in both landscape structure and its dominant features. Viticultural dominance had ended in Modra and Svätý Jur, and pastures filled $17 \%$ of the Svätý Jur total area, while non-forest wood-species vegetation took up 27\% of the Modra area. In direct contrast, vineyards regained dominance in Seleštany, with $74 \%$ of the total area. The $4^{\text {th }}-6^{\text {th }}$ CLC hierarchical levels reveal that small block staked vineyards disappeared in all study areas and only their small fragments remained

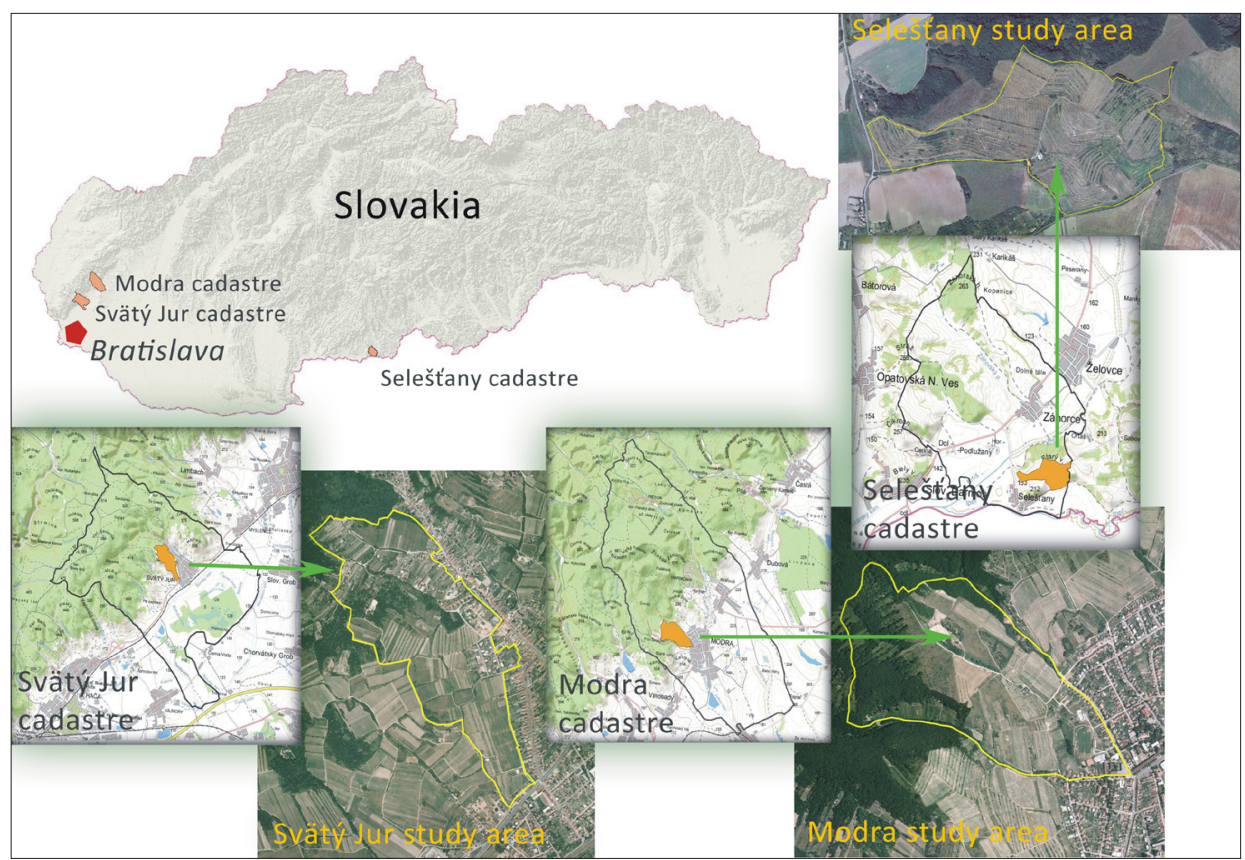

Fig. 1: Location of case study areas in Slovakia. Source: authors' elaboration

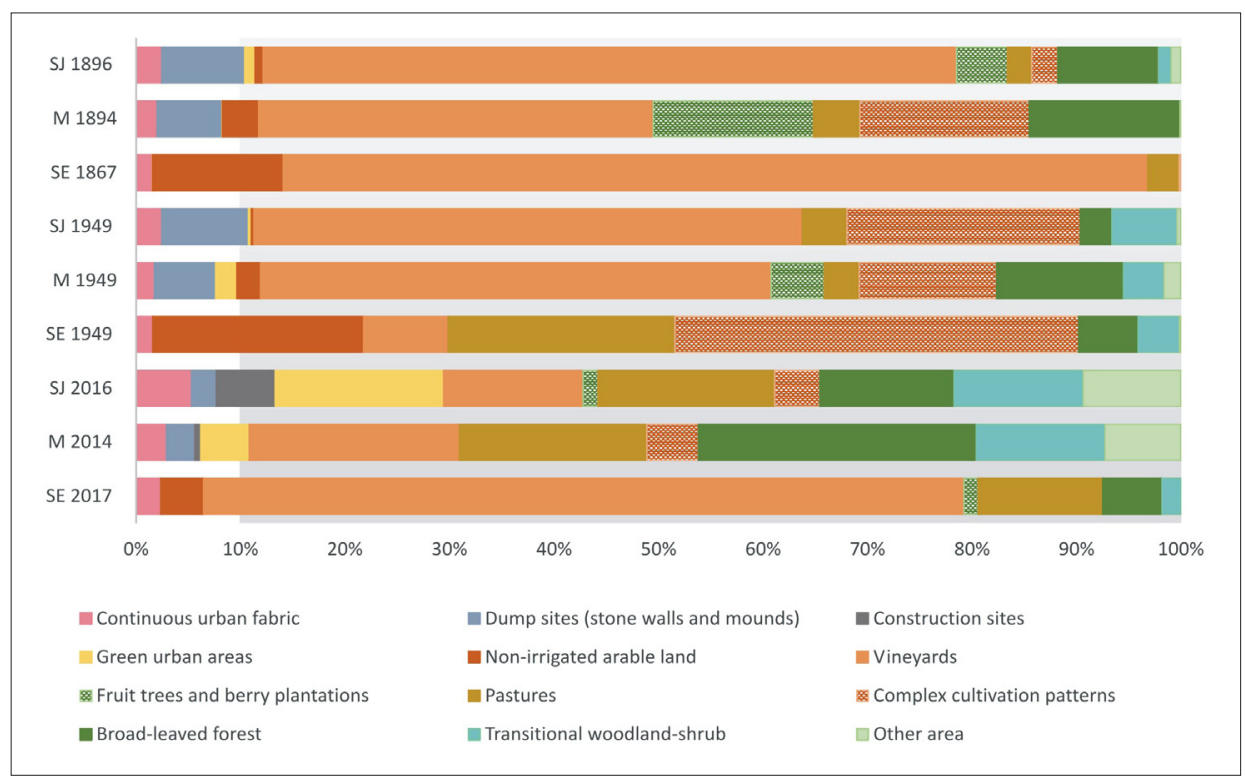

Fig. 2: Land cover at the $3^{\text {rd }}$ hierarchic level in the study years. Classes under 5\% of the study areas are grouped under "other area"; SJ = Svätý Jur study area; $M=$ Modra study area; SE = Selešt'any study area Source: authors' computations 
within complex cultivation patterns in the Svätý Jur and Modra study areas. Modern terraced vineyards, which in the collectivist era covered 15\% of Modra, 20\% of Svätý Jur and 56\% of the Seleštany study area, decreased in 2015-2016 to $4 \%$ in Modra and Svätý Jur and only slightly to 51\% in Seleštany. Similarly, the area of modern non-terraced vineyards went down from $34 \%$ to $14 \%$ in Modra, from $12 \%$ to $2 \%$ in Svätý Jur. In the Seleštany study area there was only a negligible decrease of them.

Traditional agrarian stone walls and mounds decreased significantly to 2-3\% in the Modra and Svätý Jur study areas. Vineyard bench terraces had appeared as a new agrarian land form in all study areas under collectivism, with $12 \%$ of the total Modra area, $21 \%$ of Svätý Jur and $50 \%$ of the Seleštany case study area.

\subsection{Types of landscape changes}

The comparison of $4^{\text {th }}-6^{\text {th }}$ hierarchical level LC in all studied years identified the types of landscape changes in both study periods (see Tab. 1), with $57 \%$ of the Modra territory and $64 \%$ of Svätý Jur remaining unchanged during the first study period. The most significant change was the 19\% agricultural extensification in Svatý Jur and 22\% intensification in Modra, while Seleštany experienced extensification as the most significant change with over $62 \%$ of its territory.
In the second study period, substantially smaller study areas remained unaltered, with only $23 \%$ changed in Modra and $14 \%$ in Svätý Jur. There were two opposing processes, with $20 \%$ agricultural extensification in Modra and $24 \%$ in Svätý Jur, and 21\% intensification in Modra and 23\% in Svätý Jur. Urbanisation became more significant in Svätý Jur, with a $0 \%$ to $13 \%$ increase. In this period, Seleštany experienced agriculture intensification on $64 \%$ of its territory, together with $20 \%$ extensification and $25 \%$ succession.

Parts of the large-scale terraced and non-terraced vineyards again transformed into grassland, complex cultivation patterns and shrubs after socialism, resulting from extensification of agriculture and succession. This was most evident in the terraced vineyards, with $11 \%$ in Svätý Jur and $30 \%$ in Seleštany. In contrast, there was an $8 \%$ transformation of non-terraced vineyards in Modra, and up to $7 \%$ of large block terraced vineyards in Svätý Jur were affected by urbanisation.

\subsection{Driving forces of change}

The phylloxera epidemic in the second half of the $19^{\text {th }}$ century was the major natural driver of vineyard decreases throughout Europe (Poláček and Poláček, 2010). Concurrently, political drivers strongly influenced viticultural development between the mid- $19^{\text {th }}$ century and the first half of the $20^{\text {th }}$ century. These included land

\begin{tabular}{crrrrrrrrrr}
\hline $\begin{array}{c}\text { Type of change } \\
(\%)\end{array}$ & A & S & E & DU & W & WO & D & I & U & O \\
\hline SJ 1896-1949 & 0.1 & 3.8 & $\mathbf{1 8 . 6}$ & 0.0 & $\mathbf{6 4 . 5}$ & 1.6 & 5.5 & $\mathbf{4 . 8}$ & 0.3 & 0.6 \\
M 1846-1949 & 0.8 & 2.8 & $\mathbf{1 2 . 0}$ & 0.0 & $\mathbf{5 7 . 2}$ & 1.1 & 2.5 & $\mathbf{2 2 . 2}$ & 0.8 & 0.1 \\
SE 1846-1949 & 5.7 & 3.9 & $\mathbf{6 2 . 4}$ & 0.0 & $\mathbf{1 0 . 0}$ & 0.0 & 0.0 & $\mathbf{1 7 . 9}$ & 0.0 & 0.0 \\
SJ 1949-2016 & 11.9 & 9.9 & $\mathbf{2 7 . 2}$ & 0.1 & $\mathbf{1 3 . 7}$ & 0.1 & 2.2 & $\mathbf{1 9 . 2}$ & 13.7 & 1.2 \\
M 1949-2014 & 15.2 & 13.7 & $\mathbf{2 0 . 3}$ & 0.2 & $\mathbf{2 3 . 1}$ & 0.0 & 2.0 & $\mathbf{2 0 . 9}$ & 4.6 & 0.2 \\
SE 1949-2016 & 3.5 & $\mathbf{2 5 . 2}$ & $\mathbf{1 9 . 7}$ & 0.0 & 7.5 & 0.5 & 5.2 & $\mathbf{3 7 . 8}$ & 0.5 & 0.0 \\
\hline
\end{tabular}

Tab. 1: Types of study area changes in the two periods: A-afforestation; S-succession; E-extensification of agriculture; DU-de-urbanisation; WO-woodland opening; W-without changes; D-deforestation; $I$ - intensification of agriculture; $U$ - urbanisation (Note: the most significant changes above 10\% of the study area are in bold); $S J=$ Svätý Jur study area, $M=$ Modra study area , SE = Seleštany study area Source: authors' calculations

reforms and land ownership changes before and after the collapse of the Austro-Hungarian Empire, and the intervening wars reduced the labour market. In addition to political factors, economic and technological drivers also acted here, such as the growing labour shortage notably due to increased industry and the decline in the demand for grape vines from increasing foreign competition, the economic crisis and also an increase in beer consumption (Demo et al., 2001).

The persistence of the Modra and Svätý Jur vineyards in the first period may well have been linked to strong political and economic drivers at the national level, because the state supported vineyard renewal through tax relief and free vine grafts resistant to phylloxera (Burdová, 2012). The wealthy vineyard owners made excellent use of these opportunities and the Svätý Jur and Modra municipalities, which were economically dependent on grape and wine production, had a strategic advantage due to their proximity to Bratislava, because this was the centre of the Slovak economy and the most important commercial outlet. In contrast, Seleštany was in a region where grape vines were not the only crop which supported farmers' material dependence (Drábiková, 1989).
Therefore, wine growing preservation there was difficult in this financial situation, and this was further exacerbated by political drivers including the erection of bulwarks on the Czechoslovak-Hungarian border in 1937 and the surrender of this territory to Horthy's Hungary in 1938-1945 (Antolov, 2007).

Socialist collectivism proved to be the common technological driver for LC changes in all three study areas in the second period. The extensive terrace construction in the 1960s and 1970s required conversion of relief and soils, and this was compounded by typical abandonment of traditional Svätý Jur and Modra vineyards situated in higher and more difficult cultivation sites. Farmers were forced to join socialist agricultural cooperatives and they found working with machinery in large-scale vineyards easier than the heavy manual labour in traditional vineyards. A further political driving force for the decrease in traditional vineyard areas was the transfer of the German population after the Second World War, and many of these were experienced wine growers. In addition to technological and political factors, the natural drivers related to vineyard availability and location also played a role. 
Further significant changes in the vineyard landscape after 1989 were caused by vineyard abandonment in the Svätý Jur and Modra study areas and their partial transformation into built-up areas. The major causes here were the political drivers such as withdrawal of socialist agricultural subsidies, the consequent attenuation of vinegrowing in cooperative farms and land restitution. The increased developer pressure for high-density housing on the lucrative plots also played a role in the significant economic factors of land cover change. There have been signs of winegrowing revival in the last 5 to 10 years, however, especially in the Seleštany study area.

The current differences in vineyard management and the overall intensity of land use in the study areas are reflected in the rate of utilisation of agri-environmental subsidies. While subsidies are drawn on $81 \%$ of the Seleštany study area, this is reduced to $3-4 \%$ of the Svätý Jur and Modra areas (LPIS, 2016). This temporary political driver therefore affects the case study areas to differing degrees. Farm structure and size is a further local technology driver, which suggests a potential for preserving viticulture in the study areas. While socialist cooperatives ceased to exist in Svätý Jur, where there are now 26 individual vinegrowers, they continue in Modra where one cooperative is the second largest employer in the town, competing with 35 individual vinegrowers. These study areas are distinctly different to Seleštany, where a single vinegrower manages all vineyards in this study area.

\subsection{Landscape diversity and its spatial and temporal variation}

Table 2 highlights the LDI values initially calculated as the square grid average for individual study areas and their changes over the selected years. There is an obvious trend in LDI increase over the considered years and decreased territory with zero diversity, thus signifying relatively complete homogeneity in Svätý Jur and Seleštany. In contrast, the trends are less clear in Modra, which has a slight increase in zero-diversity territory.

Table 2 also presents the selected metrics for individual study areas as a whole, without the use of the square grid for the considered years. A comparision of the results for both metrics groups reveals that the individual landscape metrics do not always provide the same, or even vaguely similar, variation over time. The SHDI values are calculated as an average of the values for individual grid squares and those for the study area as a whole. Although these mostly change in the same manner, discrepancies exist between the first period in Modra and the second period in Seleštany. These differences result from the dissimilar scale of SHDI value assessments, where our $625 \mathrm{~m}^{2}$ squares overcome problems created in study areas dozens of hectares in size. Transformation of the Seleštany study area into modern vineyards in the $2^{\text {nd }}$ period proves interesting, because SHDI and PRha decreased while NPha, TEha and MPS increased. This is related to the predominant use of the Seleštany study area for vine-growing on modern terraces.

\begin{tabular}{|c|c|c|c|c|c|c|c|}
\hline \multirow{2}{*}{$\begin{array}{c}\text { Study } \\
\text { area/year }\end{array}$} & \multicolumn{2}{|c|}{ LDI assessment in the grid } & \multicolumn{5}{|c|}{ LDI assesment in the whole territory of study area } \\
\hline & $\begin{array}{c}\text { Zero SHDI } \\
\text { (\% of study area) }\end{array}$ & $\begin{array}{c}\text { Mean SHDI } \\
\text { calculated from grid }\end{array}$ & SHDI & PRha & NPha & MPS (ha) & TEha $(\mathrm{m})$ \\
\hline SJ 1896 & 32.2 & 0.174 & 0.801 & 0.27 & 2.92 & 0.34 & 483 \\
\hline SJ 1949 & 26.1 & 0.196 & 0.943 & 0.24 & 2.86 & 0.35 & 509 \\
\hline SJ 2016 & 18.7 & 0.244 & 1.187 & 0.33 & 4.47 & 0.22 & 692 \\
\hline M 1894 & 24.2 & 0.198 & 0.900 & 0.14 & 2.68 & 0.37 & 479 \\
\hline M 1949 & 25.1 & 0.196 & 1.035 & 0.27 & 2.69 & 0.37 & 470 \\
\hline M 2015 & 26.6 & 0.219 & 1.208 & 0.48 & 4.48 & 0.22 & 632 \\
\hline SE 1867 & 58.8 & 0.080 & 0.493 & 0.16 & 0.74 & 1.35 & 197 \\
\hline SE 1949 & 30.1 & 0.176 & 1.003 & 0.30 & 2.38 & 0.42 & 408 \\
\hline SE 2016 & 16.1 & 0.262 & 0.815 & 0.23 & 4.56 & 0.22 & 876 \\
\hline
\end{tabular}

Tab. 2: Chosen LDI metrics from a) grid, and b) whole territory. Chosen landscape metrics for the whole study area: SHDI-Shannon diversity index; PRha-number of patch types per ha; NPha-number of patches per ha; MPS - mean patch size; TEha - total edge per ha; SJ - Svätý Jur, M - Modra, SE - Selešt'any study area

Source: authors' calculations

\begin{tabular}{|c|c|c|c|c|c|c|c|}
\hline & $\begin{array}{c}\text { Sum of } 4^{\text {th }} \text { and } 5^{\text {th }} \\
\text { category of LDI } \\
(\% \text { area })\end{array}$ & $\begin{array}{c}\text { Average } \\
\text { SHDI (grid) }\end{array}$ & NPha & $\begin{array}{c}\text { MPS } \\
\text { (ha) }\end{array}$ & PRha & TEha & $\begin{array}{c}\text { SHDI } \\
\text { (whole area) }\end{array}$ \\
\hline $\begin{array}{l}\text { Sum of } 4^{\text {th }} \text { and } 5^{\text {th }} \\
\text { category of LDI (\% area) }\end{array}$ & & 0.971 & 0.959 & -0.910 & 0.516 & 0.910 & 0.768 \\
\hline Average SHDI (grid) & & & 0.938 & -0.910 & 0.410 & 0.947 & 0.697 \\
\hline NPha & & & & -0.839 & 0.613 & 0.947 & 0.704 \\
\hline MPS (ha) & & & & & -0.496 & -0.779 & -0.784 \\
\hline PRha & & & & & & 0.736 & 0.758 \\
\hline TEha & & & & & & & 0.030 \\
\hline SHDI (whole area) & & & & & & & \\
\hline
\end{tabular}

Tab. 3. Matrix of correlations between selected LDI metrics (abbreviations as in Tab. 2). The values with significant correlation are in bold $(r \geq 0.9)$. Source: authors' calculations 
Table 3 presents a correlation analysis between the following selected metrics:

- the PRha parameter defines the patch richness per hectare, and here it equals the number of LC types per hectare, while the SHDI metrics are based on the number of LC types. PRha, however, has no significant relationship with the SHDI value either over the gridbased average or overall for the entire study area;

- in contrast, the average SHDI value of the grid squares increases with increasing areas with high $4^{\text {th }}$ and $5^{\text {th }}$ LDI degrees. The NPha and TEha metrics concomitantly increase and the average patch size (MPS ha) decreases.

The above correlations show that the changes in landscape diversity were more affected by changes in quantitative landscape characteristics rather than the qualitative characteristics which reflect land use diversity.

The map in Figure 3 highlights the changes in land diversity (LDI) in both periods.

Although LDI in the Svätý Jur study area in 1949 had increased compared to 1896 , over $56 \%$ of the extent of the study area underwent no LDI change, especially in the central part. Furthermore, changes in the LDI distribution during the $2^{\text {nd }}$ period were mainly caused by vineyard terracing and housing extension.

The highest LDI changes in the Modra study area in the 1st period are concentrated along the north-eastern edge of the study area, but in the $2^{\text {nd }}$ period they are confirmed in the central part, at the boundary of the hillly land and mountains, and also in the southern part of the study area where urban housing has increased. In contrast to Svätý Jur, the Modra LDI increase in the second period was not induced by the construction of terraced vineyards but mostly by increased housing adjacent to the urban area. Another typically distinct form of LDI growth was identified in the higher and more dissected study area locations where spaces between stone mounds, covered originally by the traditional staked vineyards, were extensified to diversified mosaics of non-forest woody vegetation and overgrown meadows and pastures.

The most extreme LDI changes, however, occurred in the Seleštany study area, where the distribution of LDI values varied significantly in each considered year. The fraction of the territory with high $4^{\text {th }}$ and $5^{\text {th }}$ SHDI degree LDI increased here from $2 \%$ in 1867 to $26 \%$ in 2016 . In addition, almost $60 \%$ of the study area was homogeneous in 1867 , with the highest homogeneity of the three study areas, but this decreased to the lowest of the three study area values at $16 \%$. These changes show the intensity of Seleštany transformation, distinguished by high variability in LC types and consequent high LDI.

Areas with the higher $4^{\text {th }}$ and $5^{\text {th }}$ SHDI degree LDI increased significantly in all study areas and covered higher proportions of the total areas in 2015/2016 than in the $19^{\text {th }}$ century. In addition, the extent of areas with zero LDI in the Svätý Jur and Seleštany study areas experienced downward trends in both periods, while Modra registered no significant change.

\section{Discussion}

\subsection{Methods}

The analysis of LC and LDI changes is a standard tool in evaluating landscape structure, and it is therefore used in many studies. For this study, however, we added detailed LC/LU mapping to obtain dynamic landscape information at the local level. The proposals for nomenclature of Corine Land Cover (CLC) mapping on 1:10,000 and 1:50,000 large scales were published by Feranec and Otahel' (1999) and Kopecká (2006). The proposed CLC classifications can be supplemented and further subdivided depending on the purpose of the evaluation, so we adapted it to the specific local features of distinct proportions of vineyard landscape relief forms. Detailed LC analysis from aerial images and

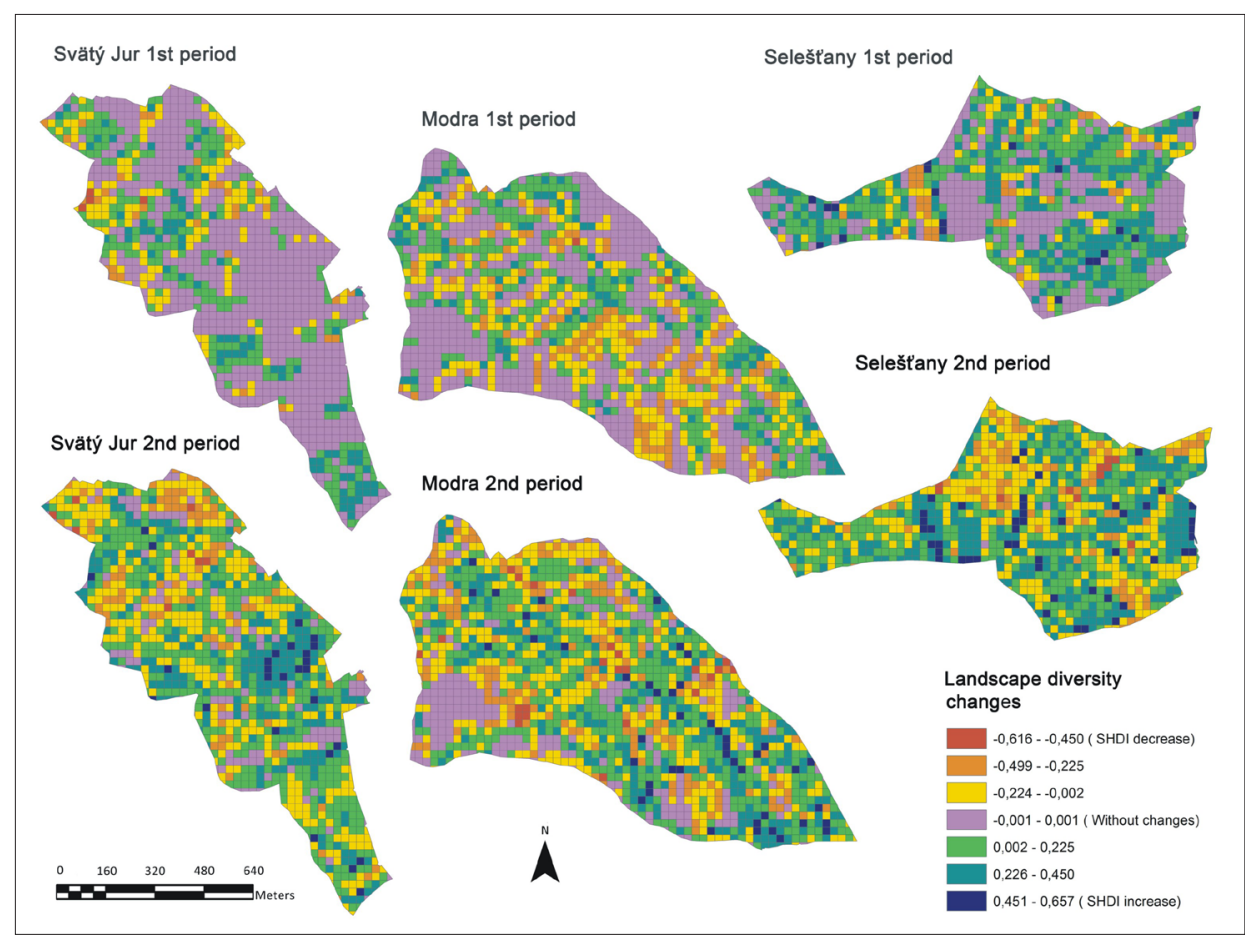

Fig. 3: Landscape diversity changes in individual study areas over the two periods ( $1^{\text {st }}$ period - between the chosen $19^{\text {th }}$ century years and 1949: $2^{\text {nd }}$ period - between 1949 and 2015/2016)

Source: authors' calculations and map elaboration 
historical cadastral maps then enabled identification of old man-made structures (Hamre et al., 2007) and diverse land-use forms which are generally mapped on a broader scale in one LC class type. The cadastral maps are the most important historical map sources, compared for example to Military Survey maps, because of their accuracy and large 1:2,880 scale (Bruna and Křováková, 2006; Domaas et al., 2007).

The 1989-1990 end of the socialist period led to major political and economic changes, and the lack of data for this period distorts our evaluation of LC and LDI changes to some extent. The second 1949 to 2000s period covers both socialist and post-socialist eras and these have very different trends. Disentangling these, however, presents a topic for further research.

The emergence of modernised vineyards during collectivisation had a significant effect on landscape changes in the second observed period. Many vineyards were abandoned after the fall of socialism and their original area remains unknown; therefore we created a map layer documenting the extent of large-scale terraced and nonterraced vineyards created during this period. These data enabled relatively accurate analysis of the extent and nature of the changes. We then analysed additional data sources, including historical archive records and historical monographs, to ascertain how the traditional vineyard landscape looked, and then to identify the driving forces for its change. This aggregation of data and maps is a common method of researching fine-structured traditional landscapes (Cullotta and Barbera, 2011; Ellis et al., 2009; Kizos et al., 2010; Špulerová, et al., 2011).

Analysis of the LC and LDI changes was based on the large LC map, and multiple landscape metric types were used for LDI calculations. These ranged from the simple patch richness index to the more complex Shannon diversity index (SHDI) and Simpson diversity index (SIDI) (Otahel' et al., 2004; Ramezani and Holm, 2011; Velázquez et al., 2019). Although we did not find precise fine scale studies to assess the landscape diversity of terraced areas, the studies by Agnolleti et al. (2015) and Kladnik et al. (2016) were the closest to our research topic. Agnoletti et al. (2015) used the terracing intensity index combined with a land use database to study the quantitative distribution of terraced landscapes on a regional level. Kladnik et al. (2016) then evaluated the diversity of both traditional and new terraced landscapes in pilot settlements using various landscape indices, including patch richness (PR), SHDI and the Shannon evenness index (SHEI).

The calculation of LDI on a regular grid of squares or hexagons provides additional information on the spatial distribution of LDI values in the landscape (Boltižiar, 2007; Halada et al., 2011; Otahel' et al., 2002, 2004; Plexida et al., 2014). In addition, our method enables the temporal and spatial comparison of LDI values expressed by SHDI values. These data acquired from a $25 \times 25 \mathrm{~m}$ grid of squares, are therefore sufficiently detailed for use in practical landscape management.

While, a possible deficiency in this method may be that interpretation of some additional LDI metrics is limited by the small area of the grid square and the relatively small edge length, Boltižiar (2007) applied $50 \times 50 \mathrm{~m}$ and $100 \times 100 \mathrm{~m}$ square grid sizes and has supported our results by suggesting that "using a smaller square size somewhat eliminates the impact of minimum area classes on LDI calculation". Further, Plexidaa et al. (2014) also recommended adapting the extent of the landscape grid to the LC mapping scale.

\subsection{Major trends in our study areas compared to other European vineyard landscapes}

The first study period established no clear developmental trends in changes or agricutural extensification, and LC changes assessed by fine-scale mapping correlated with the changing trends in vineyard landscapes published for both regional areas and Europe. A diminished traditional stakedvineyard area is evident in the first period in the Svätý Jur and Seleštany study areas, and a decreasing vineyard area trend has also been noted between 1880 and 1950 in the Czech Eastern Moravian area (Skokanová et al., 2009) and also in Catalonia and Tuscany (Olarieta et al., 2008; Agnoletti, 2007). In contrast, the increased vineyard area in this period in Modra is thought-provoking, but it is most likely that the local vine-growers were more experienced in using the available institutional and economic tools to their advantage.

The second period revealed a marked decrease in vineyard extent in Svätý Jur and Modra, and we also identified a similar decrease throughout Slovakia from 15,250 ha in 1945 (Demo et al., 2001) to 10,500 ha in 2017 (Štatistická ročenka Slovenskej republiky, 2016). The Slovak decrease must be taken in context, however, with a significant 30,840 ha increase in vineyard area during socialism, (Demo et al., 2001) and the following post-socialist decline. Studies in the Czech Republic also confirmed this trend (Demek et al., 2007; Demek et al., 2008; Skokanová et al., 2009; Havlíček et al., 2009; Havlíček et al., 2011). The major reasons for the marked decrease in the extent of the Modra and Svätý Jur vineyards were their profitable location close to Bratislava, with a significant demand for building lots, and the attitudes of new owners after land restitution, competing with wine-makers who wanted to rent or buy the lots for vineyard use (Krnáčová and Štefunková, 2011; Štefunková et al., 2011; Lieskovský et al., 2013).

The land restitution and loss of production subsidies to cooperative farms after socialism caused extensification and the abandonment of the agricultural landscapes of post-socialist countries (Kuemmerle et al., 2016; van Vliet et al., 2015), and this especially affected the vineyards. The continuity of small family farms had been severely interrupted following the transfer of the autochthonous German population (Skokanová and Eremiášová, 2012) and collectivism (Cambel, 2005). This contrasted sharply with traditional vine-growing areas in Western and Southern Europe, where farms were gradually structured according to their size, ownership and the preservation of traditional practices (Caraveli, 2000; Cots-Folch et al., 2009). The development of contemporary family vineyards originated mostly after 1990 in the Svätý Jur and Modra study areas, but this is strongly limited by the pressure of investors and the interests of landowners to sell the land for construction purposes.

Although we did not establish the precise percentage of vineyards in individual farms, we confirmed many small farms in Svätý Jur and Modra and only one vine-grower managing land in the Seleštany study area.

Large block vineyards originated in Slovakia during socialism, followed by abandonment in the transition period (Lieskovský et al., 2013), and finally the greatest change in 
vineyard use between 1990 and 2006 was to ploughed fields. This was largely due to the more favourable and profitable subsidies for arable land than vineyard cultivation after Slovakia's 2004 accession to the EU. Further, Špulerová et al. (2017) recorded that abandonment was most pronounced in the large block terraced vineyards.

The 1990s saw the commencement of Western Europe's massive support for the EU CAP, and this caused intensification and increased cropland area (Kuemmerle et al., 2016). This included vineyards, and especially those on the hilly slopes of Mediterranean areas (Cots-Folch et al., 2006; Ramos et al., 2007). Heavy land levelling and terracing was reinforced there by the EU subsidy policies (Cots-Folch et al., 2008), and the massive financial support for viticultural development in the EU parallels the modernisation of Central and Eastern European vineyards in the socialist era.

Extensification and the abandonment of traditional vineyards in our study areas occurred simultaneously with the modernised vineyard intensification and subsequent abandonment in the second half of the $20^{\text {th }}$ and beginning of the $21^{\text {st }}$ centuries. This abandonment of traditional vinegrowing areas in the second half of the $20^{\text {th }}$ century was also common in other Slovak and European wine regions (Agnoletti, 2015; Incze and Novák, 2016; Lieskovský et al., 2015; Petanidou et al., 2008). The driving factors here were agricultural industrialisation, labour loss to cities and extensive urban development (Olarieta et al., 2008; Tarrolli et al., 2014).

The abandonment of terraced areas farthest from villages, especially in the Central Pyrenees and the Iberian Range, and on land that was either marginal or hard to mechanise, has been documented by several authors: Arnáez et al. (2011); Cots Folch et al., (2006); GarcíaRuiz et al. (1996); and Lasanta (1988). Momirski and Kladnik (2009) have reported greater grass overgrowth and afforestation on Slovenian traditional terraces than on non-terraced land. These studies support our finding of the greater abandonment of traditional terraced vineyards than non-terraced grape-growing areas, and we further confirmed slightly higher abandonment of large-block terraced vineyards than large-block non-terraced vineyards, as reported throughout Slovakia (Špulerová et al., 2017). Greater physical work and financial inputs have always been required in terraces than in non-terraced areas and this continues today. Thus, despite the benefits of greater sunlight, better microclimates, erosion prevention and current subsidies for vines on terraces, this viticultural method remains unprofitable. Further, Kladnik et al. (2016) record that although terraced vineyards are aesthetically appealing, wine-growers are now trying to increase grape yield, even at the expense of lower quality, by conversion to vertical plantations with their inherent increased landslide risk (Pipan and Kokalj, 2017).

Climate warming and the increasing northern vine cultivation boundary, could slow down vineyard abandonment or even stop it through future use of Slovak grape varieties, which remain uncultivated because of the colder climate. Matese and Di Gennaro (2015) have also claimed that it will be necessary to introduce more extensive systems of precision viticulture to eliminate damage from new, unknown diseases and pests, sudden climatic extremes and droughts that threaten grape-vines. It would be very beneficial to consider introducing irrigation in the driest areas, but this is an uncommon practice in Slovakia.
The LDI values in our case study areas had mostly an upward trend in the three considered years, but in the intervening periods most likely experienced wide fluctuations. While NPha and TEha values increased and MPS decreased, no major correlation was established between PRha and SHDI, either as a grid square average or overall. It is therefore possible that landscape diversity is increasing because of landscape fragmentation rather than greater heterogeneity in land use. In support, an increase in LDI expressed by SHDI with increasing landscape fragmentation, has been confirmed by other authors, including Carranza et al. (2007) and Forman and Godron (1986).

The construction of modern terraced vineyards and merging small-area vineyards into larger blocks affected LDI in opposing directions. The terrace construction enhanced relief dissection and landscape diversity, but the merged small-area vineyards and stone mounds removal in the study areas of Svätý Jur and Modra contributed to LDI reduction. In these areas, however, terrace construction had such a range and intensity that it resulted in an overall LDI increase despite the processes decreasing LDI. The latter included the dense pattern of terrace platforms with vine plants combined with terrace slopes with shrubby and grass-herbal vegetation, which significantly fragmented large parts of these areas. Although the heterogeneity of land utilisation was reduced here, the dense structure of semi-natural habitats on terraced slopes created the potential for increased biodiversity, as reported in Košulič et al. (2014).

In comparison, in the Seleštany study area the LDI values changed more in the $1^{\text {st }}$ period than in the $2^{\text {nd }}$ period under collectivism. This highlights the finding that the process of vineyard landscape extensification can, in some cases, lead to higher LDI increase than terrace construction under collectivism. Further, the spatial changes in LDI values are mostly unrelated to particular natural conditions, but determined by external economic and social impacts which altered the landscape structure and patch type. Therefore, a comparison of LDI changes with other territories would require precise knowledge of vineyard landscape processes under collectivism, but appropriate studies on this topic are not available.

The changes in LDI expressed by the SHDI relationship with changes in landscape metrics are also ambiguous. For example, we recorded increased NPha values in the Svätý Jur area during the $2^{\text {nd }}$ period and a concurrent SHDI increase, but despite the consensus that increased SHDI is associated with increased NPha, Seleštany had increased NPha but decreased SHDI in this period. This is supported by Arnaez et al.'s (2011) similar findings of SHDI increase and NPha decrease.

Kladnik et al. (2016) also found that "mono-tonal" areas with extensive modernised terraced vineyards have low LDI, and this is in direct contrast to our findings. In this context, the importance of the definition of the "terraced vineyard" category requires consideration. While the above-quoted authors used the system of bench terraces and bench terrace slopes in the terraced vineyard to convey one integrated LC type, we considered that bench terraces and their slopes comprise two different LC types. Our reasoning is based on the fact that bench terraces and bench terrace slopes are functionally contrasted units, including possessing differences in slope, amounts of energy received and maintained and distinct biotopes. Although distinguishing 
these types increases patch type number by only one type, the increase in edge length between terraces and slopes significantly increases the LDI value.

More recently, Foški and Zavodnik (2019) examined changes in selected landscape metrics using similar methods to those herein with stable cadastres and current land records. They analysed detailed landscape diversity changes on five sites in municipal cadastres in the Slovenian Alps and reported that the number of patches, patch richness and Simpson diversity index increased in almost all territories, including Vinolje, which focused on viticuture. The comparison of our results from 1867-2016 highlights the increase in landscape diversity metrics as well.

Analysis of the reported LDI changes also highlights ambiguities in the interpretation of the LDI values and their changes. This is especially obvious in conclusions drawn from LDI changes in collectivised agricultural landscapes. The results and their interpretation there depend on both the specific natural, social and economic characteristics of the studied area and on the methodology used. This ambiguity is indirectly confirmed by Nagendra (2002), who established differences in the order of LDI values measured by SHDI and the Simpson diversity index (SIDI) on a set of 13 territories.

\section{Conclusions}

In this paper we have analysed trends in LC and LDI changes in vineyard landscapes which have a high proportion of agrarian relief forms, especially terraced vineyards. The research was based on an examination of three selected study areas during two periods, and the LC changes determined by fine scale mapping generally correlated with trends published for regional and European vineyard landscapes.

We confirmed results from previous small-scale studies from Europe that the vine-growing landscape in our study areas in the second half of the $19^{\text {th }}$ century and its further development over 150 years, oscillated between viticultural extensification with abandonment and strong intensification. In addition, the general trend also identifies the slow disappearance of traditional vineyards and the decreased area of modernised socialist era vineyards. Our research has also established that the parallel landscape phenomena of intensification and extensification (and abandonment) determine and confirm that the general trend of shifting vineyards from higher altitudes and slopes to flatter areas, provides greater vine cultivation efficiency and increased yields. This process in Slovakia was introduced during the agricultural collectivisation. Our further research results revealed that the LDI changes are due to combined changes in the qualitative and quantitative characteristics of individual landscape patterns. Moreover, the major milestones of LC changes herein determined the LDI changes, and these were due to socialist collectivism in the 1960s and 1970s and the decline in viticulture and vineyard abandonment after 1989 .

Our initial expectations of relatively small LDI changes in the $1^{\text {st }}$ period as a result of stable ownership relationships, and an increase in LDI following the construction of new terraced vineyards during collectivism in the $2^{\text {nd }}$ period, have been generally confirmed. It has also been shown that the apparently contradictory processes of extensification and intensification of agriculture can both increase LDI, and these processes are particulaly apparent in the Seleštany study area.
The precise settings used in landscape terracing have a significant impact on resultant LDI values. The values determined in other studies, which consider the entire terraced vineyard as one unit, are significantly lower than our LDI values, where the terraced and sloped portions are treated as two separate identities with different energy and biodiversity components. These components increase the fragmentation rate expressed by edge density and SHDI.

In conclusion, our detailed evaluation of the spatial changes of LDI using a square grid and analysing the historical and current driving forces for development, established that local driving forces modify the effects of global driving forces, and also that the intensity of these forces varies considerably throughout the study areas. This was especially apparent in the significantly different development trajectories in the Svätý Jur and Modra study areas compared to Seleštany.

Finally, the ambiguous results from this study and comparable research are dependent on different landscape structure interpretation and consequent methodology. These factors highlight the necessity for a consistent approach to LDI analysis in any study territories.

\section{Acknowledgements}

This paper was prepared from the project of the Scientific Grant Agency of the Ministry of Education, Science, Research and Sport of the Slovak Republic and the Slovak Academy of Sciences: VEGA No. 2/0013/18 "Evaluation of the transformation of natural and socio-cultural diversity of the cultural landscape in Slovakia (selected case study areas)".

\section{References:}

AGNOLETTI, M. (2007): The degradation of traditional landscape in a mountain area of Tuscany during the $19^{\text {th }}$ and $20^{\text {th }}$ centuries: Implications for biodiversity and sustainable management. Forest Ecology and Management, 249(1-2): 5-17.

AGNOLETTI, M., CONTI, L., FREZZA, L., SANTORO, A. (2015): Territorial analysis of the agricultural terraced landscapes of Tuscany (Italy): preliminary results. Sustainability, 7(4): 4564-4581.

ANTOLOV, P. (2007): História Záhoriec. Záhorce, Obecný úrad.

BARBERA, G., MOTISI, A. (2017): Cultural adaptation of grapevine and traditional crops in a unique drystone landscape: the Island of Pantelleria. In: Fifth International Congress on Mountain and Steep Slope Viticulture: "Extreme viticulture: values, beauties, alliances, vulnerabilities", 29 March-1 April 2017, Conegliano, Italy [online]. [cit. 28.5.2019]. Available at: https:// docplayer.it/68664795-Quinto-congresso-internazionalesulla-viticoltura-di-montagna-e-in-forte-pendenza.html

BIDDOCCU, M., FERRARIS, S., OPSI, F., CAVALLO, E. (2016): Long-term monitoring of soil management effects on runoff and soil erosion in sloping vineyards in Alto Monferrato (North-West Italy). Soil and Tillage Research, 155: 176-189.

BOLTIŽIAR, M. (2007): Hodnotenie vývoja heterogenity a vybraných charakteristík plôšok krajinnej štruktúry. Acta Environmentalica Universitatis Comenianae, 15(2): 68-79.

BORSELLI, L., TORRI, D., ØYGARDEN, L., DE ALBA, S., MARTÍNEZ-CASASNOVAS, J. A., BAZZOFFI, P., et al. 
(2006): Land levelling. In: Boardman, J., Poesen, J. [eds.]: Soil erosion in Europe (pp. 643-658). Chichester, Wiley.

BRUNA, V., KŘOVÁKOVÁ, K. (2005): Interpretace map stabilního katastru pro potřeby krajinné ekologie. Kartografické listy, 13: 1-10.

BURDOVÁ, L. (2012): Fyloxéra a perenospóra. Historika. Malokarpatský historický občasník. Pezinok, OZ Museum Vinorum, 1(1): 34-36.

CAMBEL, S. (2005): Pätdesiate roky na slovenskej dedine. Prešov. UNIVERSUM.

CARAVELI, H. (2000): A comparative analysis on intensification and extensification in mediterranean agriculture: dilemmas for LFAs policy. Journal of Rural Studies, 16(2): 231-242.

CARRANZA, M. L., ACOSTA, A., RICOTTA, C. (2007): Analyzing landscape diversity in time: The use of Rčnyi's generalized entropy function. Ecological Indicators, 7(3): 505-510.

COMINO, R. J., SENCIALES, J. M., RAMOS, M. C., MARTÍNEZ-CASASNOVAS, J.A., LASANTA, T., BREVIK, E. C., RIES, B. J., RUIZ SINOGA, J. D. (2017): Understanding soil erosion processes in Mediterranean sloping vineyards (Montes de Málaga, Spain). Geoderma, 296: $47-59$.

Commission Regulation EC No. 1227/2000 of 31 May 2000.

COSTANTINI, E. A. C., LORENZETTI, R., MALORGIO, G. (2016): A multivariate approach for the study of environmental drivers of wine economic structure. Land Use Policy, 57: 53-63.

COTS-FOLCH, R., MARTINEZ-CASASNOVAS, J.A., RAMOS, M. C. (2006): Land terracing for new vineyard plantations in the north-eastern Spanish Mediterranean region: Landscape effects of the EU Council Regulation policy for vineyards' restructuring. Agriculture, Ecosystems and Environment, 115(1): 88-96.

COTS-FOLCH, R., MARTINEZ-CASASNOVAS, J.A., RAMOS, M. C. (2009): Agricultural trajectories in a mediterranean mountain region (Priorat, NE Spain) as a consequence of vineyard conversion plans. Land Degradation \& Development, 20(1): 1-13.

CULLOTTA, S., BARBERA, G. (2011): Mapping traditional cultural landscapes in the Mediterranean area using a combined multidisciplinary approach: Method and application to Mount Etna (Sicily, Italy). Landscape and Urban Planning, 100(1-2): 98-108.

DEMEK, J., HAVLÍČEK, M., CHRUDINA, Z., MACKOVČIN, P. (2008): Changes in land-use and the river network of the Graben Dyjsko-svratecký úval (Czech Republic) in the last 242 years, Journal of Landscape Ecology, 1(2): 22-51.

DEMEK, J., HAVLÍČEK, M., MACKOVČIN, P. STRÁNSKÁ, T. (2007): Brno and its surroundings a landscape-ecological study. In: Dreslerová, J. [ed.]: Ekologie krajiny, Journal of Landscape Ecology, 0: 32-53.

DEMO, M. et al. (2001): Dejiny pol'nohospodárstva na Slovensku. Nitra, Slovenská polnohospodárska univerzita.

DOMAAS, S. T., AUSTAD, I., TIMBERLID, J. A., NORDERHAUG, A. (2003): Historical Cadastral Maps as a Tool for Valuation of Today's Landscape Elements.
In: Palang, H., Fry G. [eds]: Landscape Interfaces. Landscape series, 1: 221-236. Dordrecht, Springer.

DRÁBIKOVÁ, E. (1989): Človek vo vinici. Bratislava, Veda, vydavatel'stvo SAV.

ELLIS, E. C., NEERCHAL, N., PENG, K., XIAO, S. H., WANG, H., YAN, Z., LI, S. C., WU, J. X., JIAO, J. G., OUYANG, H., CHENG, X., YANG, L.Z. (2009): Estimating longterm changes in China's village landscapes. Ecosystems, 12(2): 279-297.

FERANEC, J., JAFFRAIN, G., SOUKUP, T., HAZEU, G. (2010): Determining changes and flows in European landscapes 1990-2000 using CORINE land cover data. Applied Geography, 30(1) 19-35.

FERANEC, J., OŤAHEL, J. (1999): Mapovanie krajinnej pokrývky metódou CORINE v mierke 1:50 000: návrh legendy pre krajiny programu Phare. Geografický časopis, 51(1): 19-44.

FORMAN, R. T. T., GODRON, M. (1986): Landscape Ecology. New York, Wiley.

GARCIA, L., CELETTE, F., GARY, C., RIPOCHE,A.,VALDÉSGÓMEZ, H., METAY, A. (2018): Management of service crops for the provision of ecosystem services in vineyards: A review. Agriculture, Ecosystems \& Environment, 251: 158-170.

GONZÁLEZ, P. A., PARGA-DANS, E., MACÍASVÁZQUEZ, A. (2017): The political economy of wine: How terroir and intra-sector dynamics affect land use in Spain. Land Use Policy, 66: 288-292.

GREINERT, A., KOSTECKI, J., VYSTAVNA, Y. (2019): The history of viticultural land use as a determinant of contemporary regional development in Western Poland. Land Use Policy, (85): 249-258.

HAFFKE, J. (1994): Die alten Weinbergsterrassen im Ahrtal: Ein Kulturlandschaftsdenkmal des Mittelalters. In: Heimatjahrbuch (pp. 134-140). Ahrweiler, Kreisverwaltung.

HALADA, L., HALABUK, A., GAJDOŠ, P. (2011): High Nature Value Farmland. Životné prostredie, 45(1): 12-16.

HAMRE, L. N., DOMAAS, S. T., AUSTAD, I., RYDGREN, K. (2007): Land-cover and structural changes in a western Norwegian cultural landscape since 1865, based on an old cadastral map and a field survey. Landscape Ecology, 22: 1563-1574.

HAVLÍČEK, M., BOROVEC, R., SVOBODA, J. (2009): Longterm changes in land use in the Litava river basin, Acta Pruhoniciana, 91: 31-37.

HAVLÍČEK, M., KREJČÍKOVÁ, B., CHRUDINA, Z., BOROVEC, R., SVOBODA, J. (2011): Změny ve využití krajiny a na vodních tocích v povodí Veličky a v horních povodích Kyjovky a Svratky, Acta Pruhoniciana, 99: 5-17.

HODÁSI, M. (2007): História - Seleštany [online]. [cit. 08.08.2018]. Available at: http://www.zahorce.sk/obec-23/ historia-selestany/

INCZE, J., NOVÁK, T. J. (2016): Identification of extent, topographic characteristics and land abandonment process of vineyard terraces in the Tokaj-Hegyalja wine region between 1784 and 2010. Journal of Maps, 12(sup.1): 507-513.

KANIANSKA, R., KIZEKOVÁ, M., NOVÁČEK, J., ZEMAN, M. (2014): Land-use and land-cover changes 
in rural areas during different political systems: a case study of Slovakia from 1782 to 2006. Land Use Policy, 36: 554-566. DOI: 10.1016/j.landusepol.2013.09.018.

KIZOS, T., DALAKA, A., PETANIDOU, T. (2010): Farmers' attitudes and landscape change: evidence from the abandonment of terraced cultivations on Lesvos, Greece. Agriculture and Human Values, 27(2): 199-212.

KLADNIK, D., CIGLIČ, R., GERŠIČ, M., KOMAC, B., PERKO, D., ZORN, M. (2016): Diversity of Terraced Landscapes in Slovenia. Annales, Series historia et sociologia, 26(3): 469-486.

KOPECKÁ, M. (2006): Identifikcia a hodnotenie zmien krajiny vo vel'kej mierke (na príklade okolia Trnavy). Geografický časopis,58(2): 125-148.

KOŠULIČ, O., MICHALKO, R., HULA, V. (2014): Recent artificial vineyard terraces as a refuge for rare and endangered spiders in a modern agricultural landscape. Ecological Engineering, 68: 133-142.

KRNÁČOVÁ, Z., ŠTEFUNKOVÁ, D. (2011): Atraktivita malokarpatskej vinohradníckej krajiny a jej ohrozenie suburbanizáciou. Životné prostredie: revue pre teóriu a starostlivost’ o životné prostredie, 45(3): 128-135.

KUEMMERLE, T., LEVERS, C., ERB, K., ESTEL, S., JEPSEN, M. R., MUELLER, D., PLUTZAR, C., STURCK, J., VERKERK, P. J., VERBURG, P. H., REENBERG, A. (2016): Hotspots of land use change in Europe. Environmental research letters, 11(6): 1-14.

Land parcel information system (LPIS) 2016, Soil Science and Conservation Research Institute (SSCRI) Bratislava, Slovakia (www.podnemapy.sk)

LIESKOVSKÝ, J., BEZÁK, P., ŠPULEROVÁ, J., LIESKOVSKÝ, T., KOLEDA, P., DOBROVODSKÁ, M., BÜRGI, M., GIMMI, U. (2015): The abandonment of traditional agricultural landscape in Slovakia - Analysis of extent and driving forces. Journal of Rural Studies 37: 75-84.

LIESKOVSKÝ, J., KANKA, R., BEZÁK, P., ŠTEFUNKOVÁ, D., PETROVIČ, F., DOBROVODSKÁ, M. (2013): Driving forces behind vineyard abandonment in Slovakia following the move to a market-oriented economy. Land Use Policy: The International Journal Covering All Aspects of Land Use, 32: 356-365.

LIESKOVSKÝ, J., KENDERESSY, P. (2014): Modelling the effect of vegetation cover and different tillage practises on soil erosion in vineyards: a case study in Vráble (Slovakia) using Watem/Sedem. Land Degradation \& Development, 25: 288-296.

LUKNIŠ, M. (1977): Geografia krajiny Jura pri Bratislave. Bratislava, Univerzita Komenského.

MARTÍNEZ-CASASNOVAS, J.A., RAMOS, M. C., COTSFOLCH, R. (2010): Influence of the EU CAP on terrain morphology and vineyard cultivation in the Priorat region of NE Spain. Land Use Policy, (27): 11-21.

McGARIGAL, K., CUSHMAN, S.A., ENE, E. (2012): FRAGSTATS v4: Spatial Pattern Analysis Program for Categorical and Continuous Maps. Computer software program produced by the authors at the University of Massachusetts, Amherst. [online]. [cit. 17.05.2018]. Available at: http://www.umass.edu/landeco/research/ fragstats/fragstats.html
MOMIRSKI, L. A., KLADNIK, D. (2009): Terraced landscapes in Slovenia. Acta Geographica Slovenica, 49(1): 7-37.

NAGENDRA, H. (2002). Opposite trends in response for the Shannon and Simpson indices of landscape diversity. Applied Geography, 22: 175-186.

OLARIETA, J. R., RODRÍGUEZ-VALLE, F. L., TELLO, E. (2008): Preserving and destroying soils, transforming landscapes: soils and land-use changes in the Vallčs County (Catalunya, Spain). Land Use Policy, 25(4): 474-484.

OŤAHEL', J., FERANEC, J., CEBECAUER, T., PRAVDA, J., HUSÁR, K. (2004): Krajinná štruktúra okresu Skalica: hodnotenie zmien, diverzity a stability. Geographia Slovaca, 19.

OŤAHEL', J., FERANEC, J., MACHKOVÁ, N. (2002): Diverzita krajiny Slovenska. Geografický časopis, 54(2): 131-150.

PAVLÍK, Z., KÜHNL, K. (1981): Úvod do kvantitativních metod pro geografy. Praha, Universita Karlova, Fakulta přírodovědecká, SPN.

PETANIDOU, T., KIZOS, T.,SOULAKELLIS, N. (2008): Socioeconomic Dimensions of Changes in the Agricultural Landscape of the Mediterranean Basin: A Case Study of the Abandonment of Cultivation Terraces on Nisyros Island, Greece. Environmental Management, 41(2): 250-266.

PETIT, C., KONOLD, W., HÖCHTL, F. (2012): Historic terraced vineyards: Impressive witnesses of vernacular architecture. Landscape History, 33(1): 5-28.

PIPAN, P., KOKAJL, Ž. (2017): Transformation of the Jeruzalem Hills cultural landscape with modern vineyard terraces. Acta geographica Slovenica, (57-2): 149-162.

PLEXIDAA, S. G., SFOUGARISA, A. I., ISPIKOUDIS, I. P., PAPANASTASIS, V.P. (2014): Selecting landscape metrics as indicators of spatial heterogeneity A comparison among Greek landscapes. International Journal of Applied Earth Observation and Geoinformation 26: 26-35.

POLÁČEK, Š., POLÁČEK, M. (2010): Vinohradníctvo a vinárstvo - stručná história a súčasnoste. Nitra, Slovenská pol’nohospodárska univerzita. [online]. [cit. 12. 02. 2018]. Available at: http://www.slpk.sk/eldo/2010/ zborniky/008-10/polacek2.pdf

RAMEZANI, H., HOLM, S. (2011): Sample based estimation of landscape metrics; accuracy of line intersect sampling for estimating edge density and Shannon's diversity index. Environmental and Ecological Statistics, 18(1): 109-130.

RAMOS, M. C., PORTA, J. (1997): Analysis of design criteria for vineyard terraces in the mediterranean area of North East Spain. Soil Technology, (10): 155-166.

RAMOS, M. C., COTS-FOLCH, R., MARTÍNEZCASASNOVAS, J.A. (2007): Sustainability of modern land terracing for vineyard plantation in a Mediterranean mountain environment - The case of the Priorat region (NE Spain). Geomorphology, 86(1-2): 1-11.

RODRIGO-COMINO, J., SEEGER, M., ISERLOH, T., SENCIALES GONZÁLEZ, J. M., RUIZ-SINOGA, J. D., RIES, J. B. (2019): Rainfall-simulated quantification of initial soil erosion processes in sloping and poorly 
maintained terraced vineyards - Key issues for sustainable management systems. Science of The Total Environment, 660: 1047-1057.

SKOKANOVÁ, H., STRÁNSKÁ, T., HAVLÍČEK, M., BOROVEC, R., EREMIÁŠOVÁ, R., RYSKOVÁ, R., SVOBODA, J. (2009): Land use dynamics of the South Moravian region during last 170 years. Geoscape 1(4): 58-65.

SKOKANOVÁ, H., EREMIÁŠOVÁ, R. (2012): Changes in the secondary landscape structure and their connection with ecological stability: the cases of two model areas in the Czech Republic. Ekológia Bratislava, 31(1): 33-45.

SKOKANOVÁ, H., FALŤAN, V., HAVLÍČEK, M. (2016): Driving forces of main landscape change processes from past 200 years in Central Europe - differences between old democratic and post-socialist countries. Ekológia Bratislava, 35: 50-65.

SLAVKOVSKÝ, P. (2009): Svet na odchode. Tradičná agrárna kultúra Slovákov v strednej a južnej Európe. Bratislava, Veda, vydavatel'stvo SAV.

ŠPULEROVÁ, J., DOBROVODSKÁ, M., ŠTEFUNKOVÁ, D. (2011): Survey of historical structures of agricultural landscape in Slovakia. In: Living Landscape. The European Landscape Convention in research perspective, 18-19 October, Florence. Conference Materials. Volume II. Short Communications, pp. 88-92.

ŠPULEROVÁ, J., DOBROVODSKÁ, M., ŠTEFUNKOVÁ, D., KENDERESSY， P., IZSÓFF， M. (2017): Terraced landscapes in Slovakia. Acta geographica SlovenicaGeografski Zbornik, (57)2: 99-109.

ŠPULEROVÁ, J., ŠTEFUNKOVÁ, D., DOBROVODSKÁ, M., IZAKOVIČOVÁ, Z., KENDERESSY, P., VLACHOVIČOVÁ, M., LIESKOVSKÝ, J., PISCOVÁ, V., PETROVIČ, F., KANKA, R., BAČA, A., BARANČOKOVÁ, M., BEZÁK, P., BEZÁKOVÁ, M., BOLTIŽIAR, M., MOJSES, M., DUBCOVÁ, M., GAJDOŠ, P., GERHÁTOVÁ, K., IZSÓFF, M., KALIVODA, H., MIKLÓSOVÁ, V., DRÁBOVÁ, M., ŠATALOVÁ, B., KRIŠTÍN, A., DANKANINOVÁ, L., KALIVODOVÁ, E., MAJZLAN, O., MIHÁL, I., STAŠIOV, S., ŠOLOMEKOVÁ, T., AMBROS, M., BALÁŽ, I., HALABUK, A. (2017): Historické štruktúry polnohospodárskej krajiny Slovenska. Bratislava, Veda, vydavatelstvo SAV.

STANCHI, S., FREPPAZ, M., AGNELLI, A., REINSCH, T., ZANINI E. (2012): Properties, best management practices and conservation of terraced soils in Southern Europe (from Mediterranean areas to the Alps). Quaternary International, 265: 90-100.
Štatistická ročenka Slovenskej republiky 2016. Bratislava, Štatistický úrad Slovenskej republiky, Veda, vydavatelstvo SAV.

ŠTEFUNKOVÁ, D., DOBROVODSKÁ, M., KANKA, R., KRNÁČOVÁ, Z., BEZÁK, P., BOLTIŽIAR, M., DAVID, S., DRAMSTAD, W., ĎUGOVÁ, O., FJELLSTAD, W., GAJDOŠ, P., HALADA, L., HREŠKO, J., IZAKOVIČOVÁ, Z., KALIVODA, H., KALIVODOVÁ, E., KENDERESSY, P., KRIŠTÍN, A., MAJZLAN, O., MOYZEOVÁ, M., PETROVIČ, F., STAŠIOV, S., ŠTEFFEK, J., VAGAČOVÁ, M. (2011): Atraktivita malokarpatskej krajiny s dôrazom na historické agrárne štruktúry a biodiverzitu. Bratislava, Ústav krajinnej ekológie SAV.

TAROLLI,P., SOFIA, G., CALLIGARO,S.,PROSDOCIMI,M., PRETI, F., DALLA FONTANA, G. (2014): Vineyards in terraced landscapes: new opportunities from lidar data. Land Degrad. Develop [online]. [cit. 28.5.2019]). Available at: https://onlinelibrary.wiley.com/doi/ full/10.1002/ldr.2311

TORQUATI, B., GIACCHČ, G., VENANZI, S. (2015): Economic analysis of the traditional cultural vineyard landscapes in Italy. Journal of Rural Studies, 39: 122-132.

TURCSÁNY, J. [ed.] (2009): Svätý Jur 1209-2009. Dejiny písané vínom. Svätý Jur, Mesto Svätý Jur.

VAN VLIET, J., DE GROOT, H. L.F., RIETVELD, P., VERBURG, P. H. (2015): Manifestations and underlying drivers of agricultural land use change in Europe. Landscape and Urban Planning, 133: 24-36.

VELÁZQUEZ, J., GUTIÉRREZ, J., GARCÍA- ABRIL, A., HERNANDO, A., APARICIO, M., SÁNCHEZ, B. (2019): Structural connectivity as an indicator of species richness and landscape diversity in Castilla y León (Spain). Forest Ecology and Management, 432: 286-297.

VINATIER, F., GONZÁLEZ ARNAIZ, A. (2018): Using highresolution multitemporal imagery to highlight severe land management changes in Mediterranean vineyards. Applied Geography, 90: 115-122.

WEI, W., CHENA，D., WANG, C. L., DARYANTO, S., CHEN, L., YUA,Y., LU,Y., SUN, G., FENG, T. (2016): Global synthesis of the classifications, distributions, benefits and issues of terracing. Earth-Science Reviews, 159: 388-403.

WINKLER, K. J., Kimberly, A. N. (2016): More than wine: Cultural ecosystem services in vineyard landscapes in England and California. Ecological Economics, 124: 86-98.

ŽUDEL, J., DUBOVSKÝ, J. M. et al. (2006): Dejiny Modry. Modra, Mesto Modra, Mestský úrad Modra.

Please cite this article as:

ŠTEFUNKOVÁ, D., HANUŠIN, J. (2019): Viticultural landscapes: Localised transformations over the past 150 years through an analysis of three case studies in Slovakia. Moravian Geographical Reports, 27(3): 155-168. Doi: 10.2478/mgr-2019-0012. 


\begin{tabular}{|c|c|c|c|c|c|}
\hline 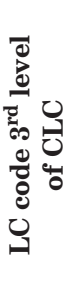 & 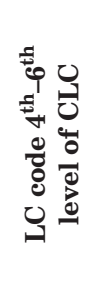 & 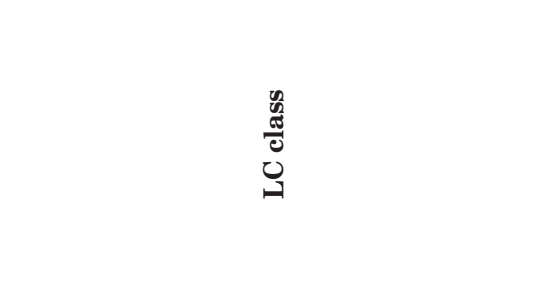 & 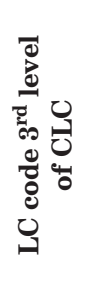 & 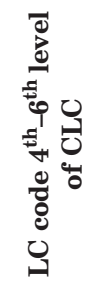 & 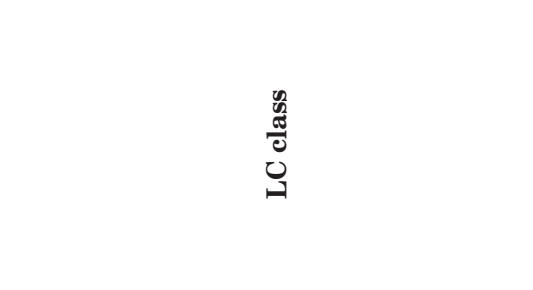 \\
\hline \multirow[t]{2}{*}{111} & 1112 & $\begin{array}{l}\text { polyfunctional areas in continuous urban } \\
\text { fabric }\end{array}$ & 221 & 221112 & wire vineyards on stone-walled terraces \\
\hline & 1113 & continuous urban fabric - family houses & & 221114 & wire vineyards on bench terraces \\
\hline \multirow[t]{5}{*}{112} & 1121 & $\begin{array}{l}\text { administrative areas in discontinuous urban } \\
\text { fabric }\end{array}$ & & 221122 & slopes of bench terraces \\
\hline & 1122 & $\begin{array}{l}\text { polyfunctional areas in discontinuous urban } \\
\text { fabric }\end{array}$ & & 221211 & small block staked vineyards (non-terraced) \\
\hline & 1123 & $\begin{array}{l}\text { discontinuous urban fabric - apartment } \\
\text { houses }\end{array}$ & & 221212 & small-block wire vineyards (non-terraced) \\
\hline & 1124 & discontinuous urban fabric - family houses & & 221221 & large-block staked vineyards (non-terraced) \\
\hline & 1125 & scattered houses (out of settlement) & & 221222 & large block wire vineyards (non-terraced) \\
\hline \multirow[t]{5}{*}{121} & 1211 & $\begin{array}{l}\text { production halls, industrial parks, logistics } \\
\text { centers }\end{array}$ & 222 & 2221 & extensive fruit orchards and chestnut groves \\
\hline & 1215 & objects of hydrological infrastructure & 231 & 2311 & grasslands without woody vegetation \\
\hline & 1217 & $\begin{array}{l}\text { stables and other objects of livestock } \\
\text { production }\end{array}$ & & 2312 & $\begin{array}{l}\text { grasslands with woody vegetation (the latter } \\
\text { under } 20 \% \text { cover) }\end{array}$ \\
\hline & 1218 & $\begin{array}{l}\text { open air parking and storage places in } \\
\text { agricultural farms }\end{array}$ & 241 & 2411 & annual crops and vineyards \\
\hline & 1219 & $\begin{array}{l}\text { storage places and barns in agricultural } \\
\text { farms }\end{array}$ & & 2412 & annual crops and orchards \\
\hline \multirow[t]{3}{*}{122} & 1221 & road network in settlement & 242 & 2421 & annual crops, grasslands and vineyards \\
\hline & 1222 & access roads to agricultural land & & 2422 & $\begin{array}{l}\text { annual crops, grasslands, orchards and } \\
\text { vineyards }\end{array}$ \\
\hline & 1223 & other reinforced surfaces and squares & & 2424 & annual crops, orchards and vineyards \\
\hline \multirow[t]{2}{*}{131} & 1311 & stone pits & & 2425 & $\begin{array}{l}\text { annual crops, orchards, vineyards and fruit } \\
\text { shrubs }\end{array}$ \\
\hline & 1312 & gravel pits & & 2426 & grasslands and vineyards \\
\hline 132 & 1322 & agrarian stone walls and mounds (kamenice) & & 2427 & grasslands and orchards \\
\hline 133 & 1331 & areas under construction & & 2428 & grasslands, orchards and vineyards \\
\hline \multirow[t]{3}{*}{141} & 1411 & parks & & 2429 & orchards and vineyards \\
\hline & 1412 & woody vegetation lines, alleys & 243 & 2431 & $\begin{array}{l}\text { grasslands and vineyards ( } 20-40 \% \text { woody } \\
\text { vegetation cover) }\end{array}$ \\
\hline & 1414 & home gardens & & 2432 & $\begin{array}{l}\text { orchards and vineyards ( } 20-40 \% \text { woody } \\
\text { vegetation cover) }\end{array}$ \\
\hline \multirow[t]{4}{*}{142} & 1421 & $\begin{array}{l}\text { sport facilities with predominantly grassy } \\
\text { surfaces }\end{array}$ & & 2434 & $\begin{array}{l}\text { grasslands, orchards and vineyards (20-40\% } \\
\text { woody vegetation cover) }\end{array}$ \\
\hline & 1423 & cottages and huts areas & & 2435 & $\begin{array}{l}\text { grasslands and orchards ( } 20-40 \% \text { woody } \\
\text { vegetation cover) }\end{array}$ \\
\hline & 1424 & swimming pools & 311 & 3111 & broad-leaved forests \\
\hline & 1425 & other sport facilities & & 3113 & non-forest woody vegetation \\
\hline \multirow[t]{2}{*}{211} & 2111 & large-block fields (above $5,000 \mathrm{~m}^{2}$ ) & 324 & 3241 & $\begin{array}{l}\text { transitional woodland-shrub (shrub } \\
\text { succession under } 40 \% \text { ) }\end{array}$ \\
\hline & 2112 & small-block fields (under 5,000 m²) & & 3242 & $\begin{array}{l}\text { transitional woodland-shrub (shrub } \\
\text { succession under } 80 \% \text { ) }\end{array}$ \\
\hline 221 & 221111 & staked vineyards on stone-walled terraces & & 3245 & forest nurseries \\
\hline
\end{tabular}

Appendix 1: Land cover classification of study areas at the $3^{\text {rd }}$ and $4^{\text {th }}-6^{\text {th }}$ level of CLC mapping 